\title{
Ecotones and Paragenese (Object) as Indicators of Structure-Dynamical Organization of Vegetation on the Background of Climate Dynamics (The Lake Baikal Basine as an Example)
}

\author{
Alexander Sizykh \\ Siberian Institute of Plant Physiology and Biochemistry, Russian Academy of Sciences, Irkutsk, Russia \\ Email: alexander.sizykh@gmail.com
}

How to cite this paper: Sizykh, A. (2017) Ecotones and Paragenese (Object) as Indicators of Structure-Dynamical Organization of Vegetation on the Background of Climate Dynamics (The Lake Baikal Basine as an Example). Open Access Library Journal, 4: e3310.

http://dx.doi.org/10.4236/oalib.1103310

Received: December 16, 2016

Accepted: January 2, 2017

Published: January 5, 2017

Copyright $\odot 2017$ by author and Open Access Library Inc.

This work is licensed under the Creative

Commons Attribution International

License (CC BY 4.0).

http://creativecommons.org/licenses/by/4.0/

\begin{abstract}
Usage of methods for determination of long-time trends in the dynamics of vegetation formation on the background of climate changes becomes more important at modern stage of the assessment of natural systems development. Solution of such a task results inevitably in necessity to correct the understanding of existing processes occurring in the vegetation cover. It allows establishing a direction of their development in system of natural factors of any territory. The aim of this study is to find peculiarities of spatial and temporal organization of phytocenoses-ecotones between altitudinal belts, zonal foreststeppe and zonal steppe, as well as one of phytocenoses reflecting paragenese as indicators of structural and dynamical organization of vegetation for different areas of Lake Baikal basine (Pre-Baikal).
\end{abstract}

\section{Subject Areas}

Biogeography

\section{Keywords}

Vegatation, Ecotones, Paragenese, Indicators of Climate Dynamics, Lake Baikal Basin

\section{Introduction}

Changes of climatic situation in the whole Central Siberia are confirmed by results of several studies [1] [2]. They suggest processes of invasion of dark-coni- 
ferous species, mainly of Pinus sibirica Du Tour, Picea obovata Ledeb., Abies sibirica Ledeb. into the zone of domination of Larix sibirica Ledeb. in the basis of Ob' and Yenisey RR. with formation of stable canopy and undergrowth consisting of dark-coniferous species in larch forests during last 30 years. Correlation and common trends of vegetation formation in the region appear-these are forestation of insular (extrazonal) steppes, increase of the role of dark-coniferous species of trees (Pinus sibirica Du Tour, Picea obovata Ledeb.) in the structure of light-coniferous (Pinus sylvestris L., Larix sibirica Ledeb.) forests. The structure of soil cover, the soils formation character and data of last paleogeographic studies [3] confirm previous suppositions that steppe communities in the studied area have mainly a temporal character and reflect the specifics of forests dynamics and evolution in Pre-Baikal at different stages of their formations.

\section{Studied Areas, Methods and Materials}

The paper is based on the materials of perennial studies of phytocenoses in the Baikal (different parts of Pre-Baikal) region forming under the conditions of extrazonality on the steppes specific phytocenoses of the bar-Yarki Island (northern shoreline of Lake Baikal) and of central part of the eastern coast of the lake. A model (key) site was selected as well in the transitional zone of interheith belts of forests on Morskoy Ridge (the Bol'shaya Sukhaya River basin) as well. It is to notice that we had no task to describe in detail physical geographic conditions of the whole Baikal Region-this is a very large volume of descriptive material. For this case simply refer to the published material-numerous specialized maps of different scales and papers with some structural peculiarities of vegetation cover of the Baikal Region territory are reflected as well in the series of maps [4] [5] and in numerous publications of researchers of Baikalian Siberia vegetation from Ya.P. Preyn [6] and M.A. Reshchikov [7] up to present-day ones [8].

Main methods of our studies were geobotanical survey and making of geobotanical descriptions for different years and vegetation periods [9] [10] for each of the plant communities (it is meant a monitoring). In the text of this paper, we present only a series geobotanical descriptions characterizing the peculiarities of the structure and of trends of phytocenoses formation (geographic coordinates are given for some descriptions) of each key site.

\section{Results}

There are in the Baikal region trends of considerable climatic changes during last decades [11] [12]. It is to notice that main climatic parameters are heterogeneity of spatial and temporal dynamics of precipitations (shiftings to main precipitations amount towards late summer and autumn in different Pre-Baikal areas), steady increase of mean annual temperatures with the rate of $0.2^{\circ} \mathrm{C}-0.5^{\circ} \mathrm{C}$ during a period of 10 years. This is by one order of magnitude higher than for the whole Northern Hemisphere.

The continental character of the climate is decreasing in the region at the 
same time due to decrease of annual temperatures amplitudes. There are trends for relative and differently directed decrease of mean annual precipitations amount, especially during October-April period with a maximum in December. There are also some dynamics in the increase of snow cover thickness and of maximal snow stocks for last 40 years for forest-steppe territories in Pre-Baikal [11] [12] and for last 50 years in taiga zone [11]. It is indicated that snow stocks and thickness are uneven for concrete territories in the region due to physical-geographic and biogeographic conditions with trend towards a relative decrease of time of snow cover, especially for forest-steppes territories of Pre-Baikal. The decrease of snow cover period suggests, in the author's opinion [11] [12], winter temperatures decrease in the region. Such trends in the snow cover formation in the Baikal region correlate with data of studies of climate dynamics for the whole North Eurasia [13]. The composition of diatom algae sediments in the bottom sediments of a closed water body (Lake Kotokel') in the East Pre-Baikal served as well as indicator of climate change in this region during Holocene (last 11,500 years [14]. It is shown here that the increase of diatoms concentration due to increase of melt waters income into the lake, indicates the increase of mean annual temperatures during different Holocene periods in the region.

Characteristics of modern trends of formation of phytocenoses-ecotones as of climate dynamics indicators in the Baikal Region

Formation of transitional communities at height belts with formation of interheight belts ecotones at the contact of polydominant dark-coniferous-lightconiferous forest and dark-cniferous taiga is characteristic for the central part on the eastern coast of Lake Baikal.

\subsection{Key Site-Middle Part of the Bol'shaya Sukhaya River Basin, Morskoy Ridge, Cental Part of Eastern Coast of Lake Baikal}

This key site, the Bol'shaya Sukhaya River basin, reflects the beginning of transition of forest forming species from light-coniferous to dark-coniferous one during last decades and under present climatic conditions in the region (Figure 1).

The peculiarities of phytocenoses structure characterizing modern dynamic trends in the formation of vegetation both on the key site and its adjacent area:

The coordinates of described area are (N52 $30^{\prime} 00^{\prime \prime}$ - E107 $21^{\prime} 29^{\prime \prime}$; N52 ${ }^{\circ} 33^{\prime} 89^{\prime \prime}$ $\left.\mathrm{E} 107^{\circ} 08^{\prime} 75^{\prime \prime}\right)$;

Shoreline. Pines (Pinus sylvestris L.) with rhododendron (Rhododendron dauricum L.) with inclusion of mountain pine (Pinus pumila (Pallas) Regel). In the second layer there are cedars (Pinus sibirica Du Tour) with soil cover consisting of beadruby (Maianthemum bifolium (L.) F.M. Schmidt. and sedge.

Shoreline. Forest with larch (Larix sibirica Ledeb.), pine (Pinus sylvestris L.), rhododendron (Rhododendron dauricum L.), cowberries (Vaccinium vitis-idaea L.) and motley grasses. Undergrowing cedars (Pinus sibirica Du Tour) 3 and more y.o., in the second layer there are cedars (Pinus sibirica Du Tour) aged up to 45 . Soil cover consists of sedge (Carex macroura Meinsh.) and mosses- 


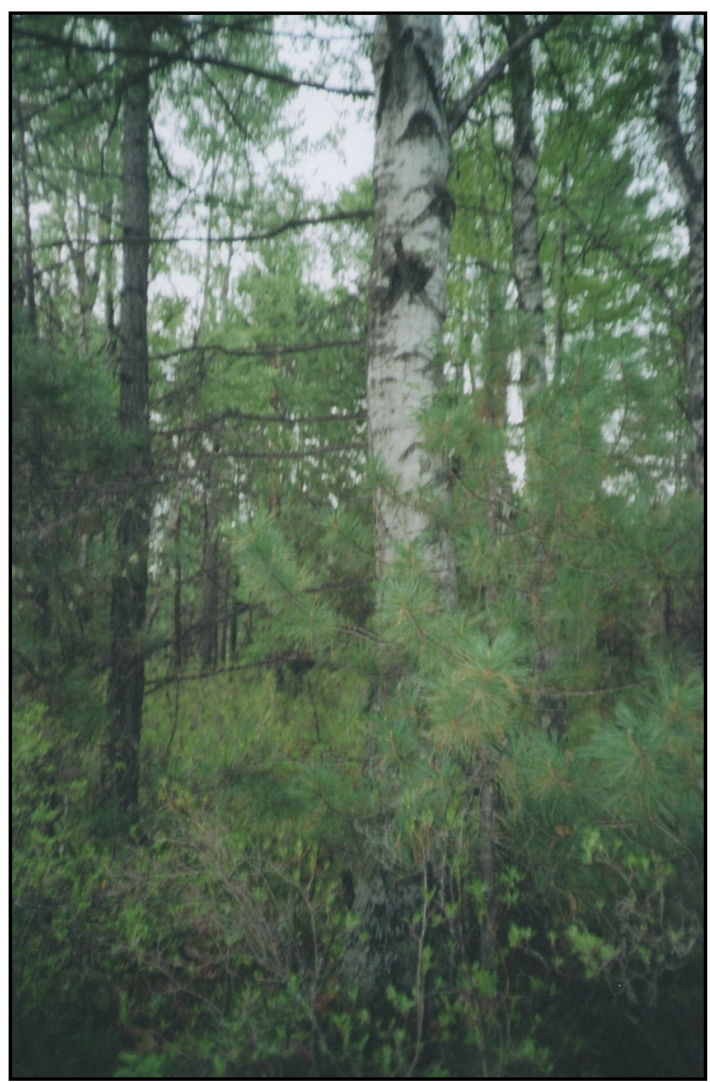

Figure 1. Key site-middle part of the Bol'shaya Sukhaya River basin, Morskoy Ridge. Territory of formation of interheight belt ecotone at the boundary of transition of polydominant dark-coniferous-light coniferous taiga into dark-coniferous one.

Abietinella abietina (Turn.) Fleisch.), Dicranum polysetum Sw., Hylocomium splendens (Hedw.) BSG.

Slope trail. Birch (Betula platyphylla Sukaczev) and aspen (Populus tremula L.) forest with underbrush of Rhododendron dauricum L. Undergrowth-cedar (Pinus sibirica Du Tour) aged from 3 to 25 with single trees of Pinus sibirica Du Tour и Abies sibirica Ledeb. up to 80 y.o. Soil cover consists of Iris ruthenica Ker-Gawler, Galium boreale L., Pteridium aquilinum (L.) Kuhn ex Decken. Probably, this community represents a succession of a dark-coniferous forest.

Low part of the slope. Reconstitution of a dark-coniferous forest instead of a light-coniferous one. Aspens (Populus tremula L.) and motley grasses with inclusion of larches (Larix sibirica Ledeb.) up to 300 y.o., undergrowth includes Pinus sibirica Du Tour and Abies sibirica Ledeb. Soil cover consists of cowberries (Vaccinium vitis-idaea L.) and mosses. In the underbrush there is rhododendron (Rhododendron dauricum L.).

Middle part of the slope. Polydominant pine (Pinus sylvestris L.) -larch (Larix sibirica Ledeb.) forest, in the second layer there are Pinus sibirica Du Tour (<50 y.o.), Abies sibirica Ledeb. (<40 y.o.) with underbrush consisting of $\mathrm{Du}$ schekia fruticosa (Rupr.) Pouzar, Rhododendron dauricum L.. Soil cover consists of Vaccinium vitis-idaea L., Carex macroura Meinsh. This community is to be considered as transitional one from polydominant light-coniferous taiga to 
dark-coniferous one. Transitional community with inclusion of Abies sibirica Ledeb., at burnt site-birches (Betula platyphylla Sukaczev), motley grasses with underwood of Rhododendron dauricum L. The soil cover is dominated by Equisetum sylvaticum L. and Maianthemum bifolium (L.) F.M. Schmidt., together with birch (Betula platyphylla Sukaczev) and motley grasses; the undergrowth includes Pinus sibirica Du Tour and Abies sibirica Ledeb. aged from 3 to 25. The underwood: Duschekia fruticosa (Rupr.) Pouzar, Rhododendron dauricum L., Ledum palustre $\mathrm{L}$. The community forms at the site of cutting and burning.

The studied area (middle part of the Bol'shaya Sukhaya River basin) is a transitional zone of polydominant dark-coniferous-light-coniferous (Figure 1) taiga to dark-coniferous one, where interheight belt ecotone forms with dark-coniferous species in the second layer and undergrowth of forests with dominance of a light-coniferous belt in the region. It is to notice here that the response of interzonal and interheight belt ecotones onto climate dynamics in the region (and this is their territorial "extension") suggests rather considerable changes in the ratio of heat and humidity of a definite radiation belt [15] characterizing zonal (and height belts) structure of the communities in the organization of the Baikal Region vegetation.

Trends in formation of phytocenoses reflecting the "paragenese" (object) as of indicators of climate dynamics in the Baikal Region

At present, there are processes of taiga formation at the site of steppificated pine and larch rare forests and steppe communities in the Baikal Region everywhere. Main environmental factor resulted in the spatial stratigraphy of the studied area is location of a concrete community in Pre-Baikalian mountains system. The exposition of mountains slopes determines only a degree of timber stands density and undergrowth abundance as well as abundance of this or that plant species among grasses communities. Climatic situation changed [14] and resulted to environmental changes in the whole Baikal Region-changed conditions resulted to establishment of rather concrete really existing objects, e.g., of steppe communities among taiga. Formation of natural systems, including vegetation, occurs under existing physical-geographic conditions simultaneously. In this case the paragenese (object) in vegetation from the viewpoint how great is the probability of phytocenoses diversity under existing environmental conditions within concrete territories called environmental zones (or height belts) in their modern transcription. As for succession, this is a directed change of communities structure within a concrete vegetation type. Phytocenoses at environments contact-extrazonal formations within environmental zones-are, as paragenese, a natural process of development of adjacent phytocenoses of common origin at a concrete territory during a definite time period.

\subsection{Key Site-Bar-Yarki Island, Lake Baikal Northern Coast}

Formation of phytocenoses reflecting other paragenese form where communities include plants species representing different environmental zones of East Siberia is characteristic for Northern Pre-Baikal (key site bar-Yarki Island, Lake Baikal northern coast, Figure 2). 


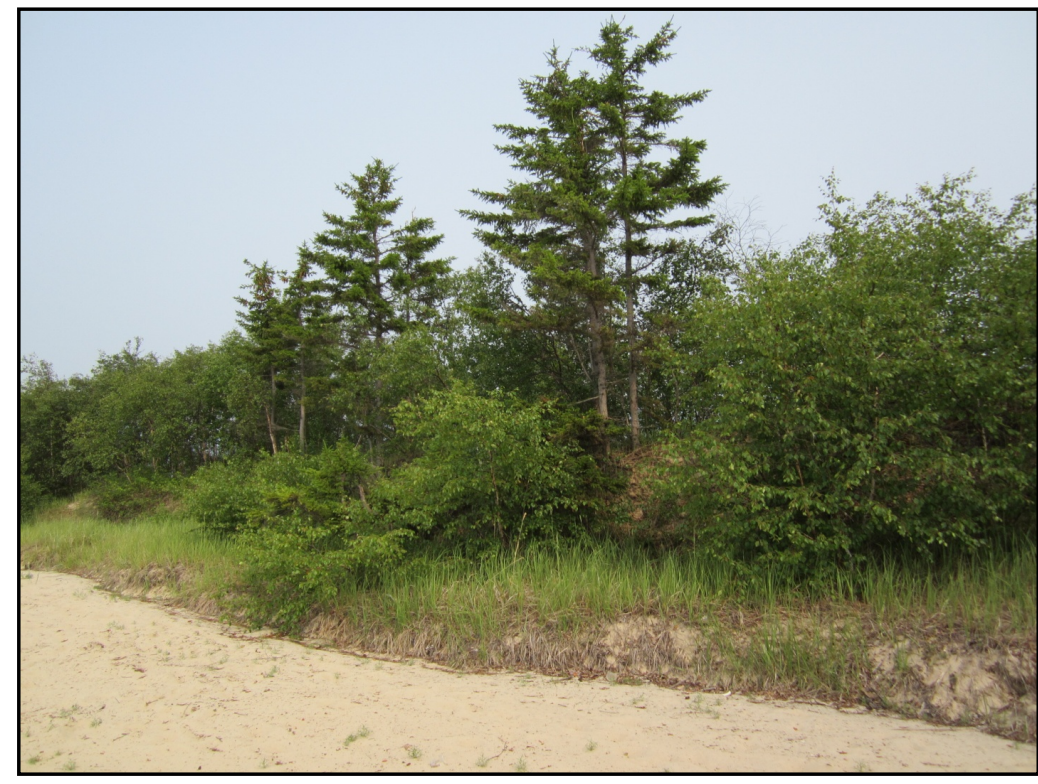

Figure 2. Key site-northern coast of Lake Baikal, bar-Yarki Island. The paragenese reflects the structure of communities where there are vegetation species representing zonal dark-coniferous and mountain taiga forest, light-coniferous forests, sub-goltsy belt, mountain tundra and steppes of North-Asian type.

Basic vegetation of sandy relief on the territory surrounding the key site (the whole bar) consists of dwarf birches with inclusions of Pinus pumila (Pallas) Regel, vegetation groups such as ledum-cassandra-sphagnum, ledumsphagnum, ledum-cowberries-sphagnum (in particular, surroundings of Nizhneangarsk settlement, coasts of the Kichera River). Here mountain pine dominates, it forms together with dwarf birches. Ledum palustre L. grows under the canopy of mountain pine and dwarf birches, in the soil cover there are mosses-Pleurozium schreberi (Brid.) Mitt., Aulacomnium palustre (Hedw.) Schwaegr., Polytrichum affine Funck, Polytrichum strictum Sm.

The phytocenoses of bar itself-Yarki Island (key site) consist of Pinus pumila (Pallas) Regel, Betula platyphylla Sukachev and Betula pubescens Ehrh. There is a rare undergrowth of Dahurian larch (Larix dahurica Lawson) together with Sorbaria grandiflora (Gwect.) Maxim. and Padus avium Miller. Soil cover of open spaces consists of Elymus sibiricus L., Festuca rubra subsp. baikalensis (Griseb.) Tzvelev., Astragalus sericeocanus Gontsch., Carex sabulosa Turcz. ex Kunth, Equisetum pratense L., Calamagrostis epigeios (L.) Roth. Under the canopy of Pinus pumila (Pallas) Regel. There are widely distributed Empetrum nigrum L., Linnea borealis L., Arctostaphylos uva-ursi (L.) Sprengel, Ledum palustre L. s. str., Vaccinium vitis-idaea L. s.str., Vaccinium uliginosum L. and synusially-Carex rhynchophysa C.A. Meyer and Carex globularis L, Empetrum nigrum L., Phyllodoce caerulea (L.) Bab., there are some specimens of Cassiope ericoides (Pallas) D. Don. There are single cedar trees (Pinus sibirica Du Tour) with undergrowth of Larix dahurica Lawson. We have to notice in particular rather expanded growth of Achnatherum splendens (Trin.) Nevski and Festuca rubra subsp. baikalensis (Griseb.) Tzvelev., with inclusions of Iris laevigata 
Fischer et Meyer.

It is to notice here that these communities form on the sandy deposits of the bar up to 10 - 15 meters thick, which just form Lake Baikal shoreline itself. The cenoses include dark-coniferous trees species, mountain pine, mosses and species characteristic for dark-coniferous forests, subgoltsy belt and mountain tundra together with representatives of dry steppes of Central Asia. Vegetation formation under these conditions (lake shoreline, massive sands deposits, a rigorous local climate) reflects the specifics of environmental and climatic conditions of this region of Pre-Baikal allowing appearing of paragenese (object) in the common structure of North Pre-Baikal vegetation cover.

\subsection{Key Site-Near-Shore Territory between the Bol'shaya Sukhaya River Basin (Site of the River Input into the Lake) up to Gremyachinsk Settlement}

Here are modern trends of formation of vegetation on the key site reflecting paragenese. Communities forming here include plants species from some environmental zones of the Baikal Region. In this case, communities of central part of Lake Baikal eastern coast from site of the Bol'shaya Sukhay River inflow into Lake Baikal to Gremyachinsk settlement (central part of Lake Baikal eastern coast) along the coast characterize the specifics of vegetation structure in this part of East Pre-Baikal (Figure 3).

The results of studies done for this key site (along the whole site of the lake shoreline suggest the following typical vegetation: rather specific forests with cedars (Pinus sibirica Du Tour), pines (Pinus sylvestris L.), brushes (Duschekia fruticosa (Rupr.) Pouzar., Rhododendron dauricum L., Vaccinium uliginosum L., Ledum palustre L.), undershrubs (Vaccinium vitis-idaea L., Empetrum ni-

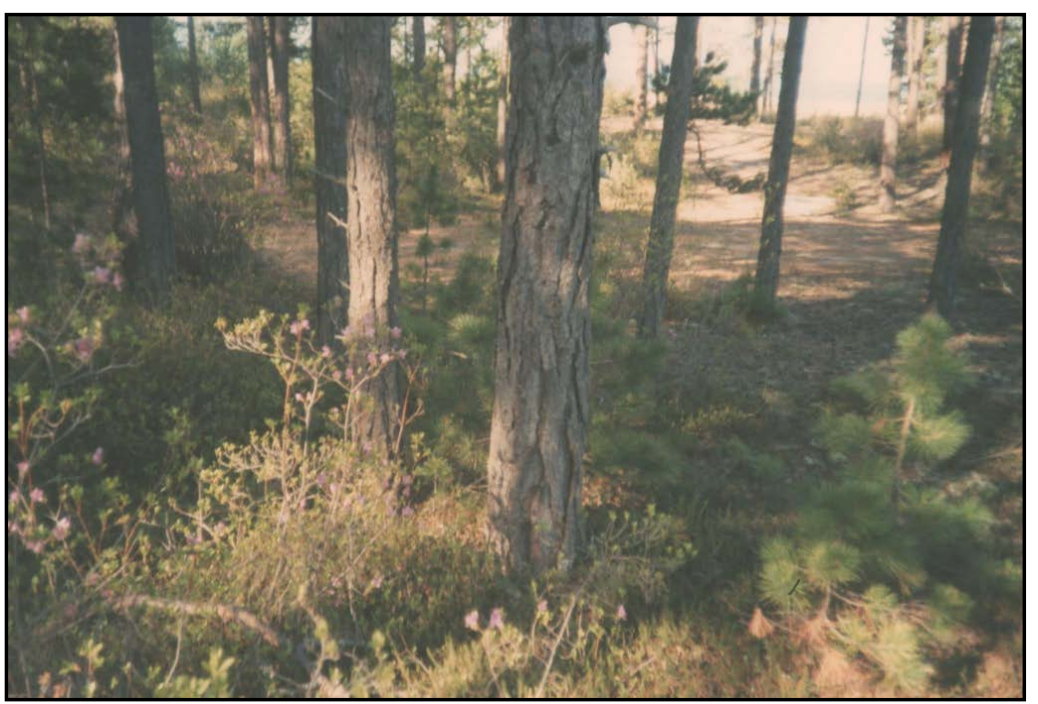

Figure 3. Key site-near-shore territory between the Bol'shaya Sukhaya River basin (site of the river input into the lake) up to Gremyachinsk settlement. Paragenese reflects the structure of vegetation including communities with dark-coniferous and light-coniferous species, mountain pine, species of subgoltsy belt and of mountain tundra, as well as representatives of North-Asian steppes. 
grum L., Andromeda polifolia L., Oxycoccus microcarpus Turcz. ex Rupr.), motley grasses (Festuca sibirica Hackel ex Boiss., Calamagrostis neglecta (Ehrh.) Gaertner., Calamagrostis arundinacae (L.) Roth., Sanguisorba officinalis L., Maianthemum bifolium (L.) F.W. Schmidt., Orchis militaris L., Equisetum pratense Ehrh.), green mosses (Polytrichum commune Hedw., Dicranum polysetum Sw., Pleurozium shreberi (Brid.) Mitt., Phtilium crista-castrensis (Hedw.) De Not., Dicranum muthlenbeckii B.S.G.), sphagna (Sphagnum palustre). There are in the second layer Abies sibirica Ledeb. and Picea obovata Ledeb. The underwood is represented by Betula pendula Roth., Betula platyphylla Sukaczev., Betula pubescens Ehrh. In different quantitative variations in the phytocenoses on the territories where they are available. These communities form everywhere on eolian sands. Such communities form along Lake Baikal eastern coast and occupy a narrow near-shore line along the slopes trails; they are well developed on eolian sands of the central part of eastern coast. It is to notice here that specific phytocenoses formed by plants species representing different environmental zones (and height belts) of Siberia form as well on other near-shore territories of Lake Baikal eastern coast and on the trail of western macro-slope of Barguzin Ridge (north eastern part of Pre-Baikal) and are characterized as a "false subgoltsy belt". According to information from paleogeographic studies in the region [14], the last statement in this case is to be discussed like in the previous example (key site bar-Yarki Island, Lake Baikal northern coast). The doubts of correctness of outlining the "false subgoltsy belt" referring to the paper by L.N. Tyulina [16] come as well from some other researchers of vegetation in this Pre-Baikal area [17]. In this case, the paragenese (object) in vegetation structure in the Baikal region is taking place.

\section{Discussion}

Taking into account the peculiarities of the modern state and development way of the communities resulting in paragenese (object) in vegetation structure of the studied area, we have to expect formation of light-coniferous taiga with perspective inclusion of dark-coniferous species, as there are trends of activation of activity of the latters in the forests at the studied territories. However, processes of steppe territories forestation within taiga zone will be restricted by anthropogenic impacts on the background of climate dynamics, mainly by the character of precipitations rediustribution according to seasons and by temperature dynamics.

The response of phytocenoses reflecting paragenese onto climate dynamics in the region during last decades is manifested by territorial "narrowing" of steppe areas with increase of forestation of extrazonal steppes [18]. This is particularly typical for extrazonal steppes in some parts of coast of Lake Baikal basine [19] as well. Another characteristic is the decrease of the role of xerophytes in the communities of zonal taiga (northern coast bar-Yarki Island, central part of Lake Baikal eastern coast) and in central part of the eastern coast of the lake-in the transitional zone of interheith belts of forests on Morskoy Ridge (the 
Bol'shaya Sukhaya River basin). These facts suggest rather considerable changes in the ratio of heat and humidity influencing intrazonal (and intrabelt) conditions of communities formation, and as a result-organization of zonal (and height belt) vegetation in the region.

\section{Conclusions}

Structural-dynamic organization of vegetation cover in Pre-Baikal areas manifested modern trends of formation and development of phytocenoses-ecotones and communities reflecting paragenese in the vegetation structure of the region. Climate dynamics in the region [11] [12], and partly-decrease of anthropogenic impact (e.g., decrease of livestock per an area unit) during several last decades in the studied areas initiated formation of transitional communities of different genesis. Modern stage of environmental evolution in the region reflects strength of position of trees in grasses phytocenoses at the considered territories with change of composition of dominant trees species. As it is known, there were during Holocene periods of spatial "widening" and "narrowing" of steppe areas. Consequently, we may state that there are in the structure of the Baikal Region vegetation different manifestations in formation of cenotic structures under transitional environmental conditions including both "ecotones" and "paragenese". It is probable that at e certain scenario of climate change, environmental zones can shift latitudinally, and areas of extrazonal steppes in zonal taiga can decrease; at the first stage, the latters can be replaced by light-coniferous forests of taiga type. It can result as well in changes in formation of the whole environment. Taking into account the peculiarities of the modern state and development way of the communities resulting in paragenese (object) in vegetation structure of the studied area, it is expecting formation of light-coniferous taiga with perspective inclusion of dark-coniferous species, as there are trends of activation of activity of the latters in the forests at the studied territories. Another characteristic is the decrease of the role of xerophytes in the communities of zonal taiga (northern coast bar-Yarki Island and the central part of Lake Baikal eastern coast. These facts suggest rather considerable changes in the ratio of heat and humidity influencing intrazonal (and intrabelt) conditions of communities formation, and as a result-organization of zonal (and height belt) vegetation in the region. The way of formation of interzonal and interheight belts ecotones in the whole region will be due in the nearest future to climate dynamics.

Due to this, understanding the history of such phenomena as "ecotones" and "paragenese" in the structure of vegetation in the Baikal Region as well as to reveal reasons of their appearing and to assess the dynamics of environment development of the region in the whole. Such communities can serve as a regional model for indication of existing processes and of occurred changes. These changes can characterize trends of possible spontaneous dynamics and anthropogenic destructions of environment under definite ecological conditions. It will be always critical to know, which is the nature of zonality, belts, extrazonality and of genesis of the environment determining zonality and extrazonality in ve- 
getation organization reflecting as well the history and the way of vegetation development. Ecological and biogeocenotic importance of ecotones and communities reflecting paragenese (object) in vegetation structure of the Baikal Region is in revealing of communities phytocenotic and typological diversity, in indication of structural-dynamic organization and in the forecast of vegetation development under concrete physical-geographic conditions at wide territories with different degrees of natural and anthropogenic resistance of the whole vegetation cover. And further studies of vegetation structure under contrast environmental conditions (environments contact communities respond much more rapidly to all climate changes) on other territories adjacent to the Baikal Region, on the territory of the whole Central Siberia will allow to reveal the peculiarities of structural-dynamic organization of environments contact communities at the continental level of vegetation cover organization. It will allow to forecast of vegetation development under different conditions of climate dynamics in time and space.

\section{References}

[1] Kharuk, V.I., Dvinskaya, M.L., Ranson, K.J. and Im, S.T. (2005) Invasion of Evergreen Coniferous Trees into the Zone of Larch Domination and Climatic Trends. Ecology, 1, 186-192.

[2] Chebakova, N.M. (2006) Probable Transformation of Siberian Vegetation Cover at Different Scenarios of Climate Changes: Abstract of Thesis... Dr. in Biol. Sci.: 03.00.16. Krasnoyarsk. 60 p.

[3] Kuz'min, M.I., Karabanov, Ye.B., Bezrukova, Ye.V., Bychinsky, B.A., Prokopenko, A.A., Kravchinsky, V.A., Gelety, V.F., Solotchina, E.P., Khursevich, G.K., Goreglyad, G.A. and Kraynov, M.A. (2008) Climate and Environment Changes in Central Asia during Late Cenozoic on the Base of Studies of Deep-Water Holes from Lake Baikal. Global and Regional Climate and Environment Changes of Late Cenozoic in Siberia. RAS SB Publishing House, Novosibirsk, 11-105.

[4] Atlas. Lake Baikal (1993) Moscow: Federal Survey for Geodesy and Mapping Publishing House. $160 \mathrm{p}$.

[5] Ecological Zoning of Baikalian Environment Territory (Map. Scale 1:1000000).: Institute of Geography of RAS SB, 2002, Irkutsk, 2 Sheets.

[6] Preyn, Ya.P. (1892) Preliminary Report on Botanical Studies of Balagansk District and Irkutsk City environments. News of East-Siberian Branch of the Russian Geographic Society, Irkutsk, 23, 29-53.

[7] Reshchikov, M.A. (1961) Steppes of the West Pre-Baikal. Nauka, Moscow, 174 p.

[8] Molozhnikov, V.N. (2014) Vegetation of Pre-Baikal. LAP LAMBERT Academic Publishing, Saarbrucken, 613 p.

[9] Field Geobotanics (1964). V. 3. Moscow-Leningrad. 530 p.

[10] Field Geobotanics (1978). V. 4. Moscow-Leningrad. 336 p.

[11] Maksyutova, Ye.V. (2012) Characteristics of the Snow Cover in Pre-Baikalian Forest-Steppe. Ice and Snow, 11, 54-61.

[12] Maksyutova, Ye.V., Kichigina, N.V., Voropay, N.N., Balybina, A.S. and Osipova, O.P. (2012) Trends of Hydroclimatic Changes at the Baikalian Environmental Territory. Geografia i Prirodnye Resursy, 12, 72-81. 
[13] Shmakin, A.B. (2010) Climatic Characteristics of North Eurasia Snow Cover and Their Variations during Last Decades. Ice and Snow, 13, 43-57.

[14] Bezrukova, Ye.V., Tarasov, P.Ye., Kulagina, N.V., Abzayeva, A.A., Letunova, P.P. and Kostrova, S.S. (2011) Palynological Studies of Lake Kotokel' Bottom Sediments: (Lake Baikal Area). Russian Geology and Geophysics, 52, 586-596.

[15] Bezdelova, A.P. (2006) Peculiarities of Trans-Baikal Zonal Location as the Basis for Development of Steppification of Vegetation Cover in the Region. Steppes of North Eurasia. Gazprom Publishing House of Orenburg Gas Exploration Survey Ltd., Orenburg, 99-102.

[16] Tyulina, L.N. (1981) Vegetation of the Barguzin Ridge Southern Part. Nauka, Novosibirsk, $86 \mathrm{p}$.

[17] Annenkhonov, O.A., Valakhovich, M. and Khodalova, I. (1999) Vegetation Belts of Barguzin Ridge: Interpretation on the Base of Ecological-Floristic Classification of Vegetation. Diversity of Vegetation Cover of the Baikal Region. Ulan-Ude. 59 p.

[18] Sizykh, A.P. (2016) Afforestation of Extrazonal Steppes in the Baikal Region. Open Access Library Journal, 3: e2362. http://creativecommons.org/licenses/by/4.0/ http://dx.doi.org/10.4236/oalib.1102362

[19] Sizykh, A.P. (2015) Mapping Studies of Phytocenoses in Environment Interfaces (as Methodical Approaches. Open Access Library Journal, 2: e2206.

http://creativecommons.org/licenses/by/4.0/

http://dx.doi.org/10.4236/oalib.1102206

Submit or recommend next manuscript to OALib Journal and we will provide best service for you:

- Publication frequency: Monthly

- 9 subject areas of science, technology and medicine

- Fair and rigorous peer-review system

- Fast publication process

- Article promotion in various social networking sites (LinkedIn, Facebook, Twitter, etc.)

- Maximum dissemination of your research work

Submit Your Paper Online: Click Here to Submit

Or Contact service@oalib.com 